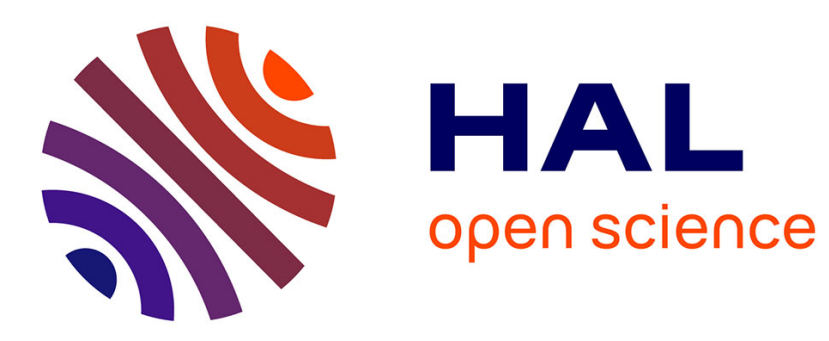

\title{
Of Times and Things. Technology and Durability
}

Bernadette Bensaude-Vincent

\section{To cite this version:}

Bernadette Bensaude-Vincent. Of Times and Things. Technology and Durability. Sacha Loeve, Xavier Guchet, Bernadette Bensaude-Vincent. French Philosophy of Technology. Classical Readings and Contemporary Approaches, 29, Springer, pp.279-298, 2018, Philosophy of Engineering and Technology, 978-3-319-89517-8. 10.1007/978-3-319-89518-5_17. hal-01820190

\section{HAL Id: hal-01820190 https://hal.science/hal-01820190}

Submitted on 21 Jun 2018

HAL is a multi-disciplinary open access archive for the deposit and dissemination of scientific research documents, whether they are published or not. The documents may come from teaching and research institutions in France or abroad, or from public or private research centers.
L'archive ouverte pluridisciplinaire HAL, est destinée au dépôt et à la diffusion de documents scientifiques de niveau recherche, publiés ou non, émanant des établissements d'enseignement et de recherche français ou étrangers, des laboratoires publics ou privés. 


\title{
Of Times and Things. Technology and Durability
}

\author{
Bernadette BENSAUDE VINCENT
}

In French Philosophy of Technology. Classical Readings and Contemporary Approaches. Sacha Loeve, Xavier Guchet, Bernadette Bensaude-Vincent eds. Springer, 2018, p. 279-298.

\begin{abstract}
To fully accomplish the "thing turn" in the philosophy of technology this paper invites shifting the attention from humans towards the world. The concept of world here refers to the complex made of the Earth with all things and living beings, including humans; it ignores the great divide between nature and society or culture. In this worldly perspective, the thing turn means adopting the perspective of things and raising questions such as how artifacts come into being, how they intervene within the world, how they change it. Such issues are vital to prevent the alienation of technology both from nature and from human beings.
\end{abstract}

\section{Keywords}

Anthropocene, environmental activism, nuclear waste, plastic waste, thing turn, worldly perspective, regimes of temporality, temporalities

Given the amount of meanings, values, norms and potentials conferred to artifacts in the recent studies of technology since the "thing turn," (Miller 1998, Preda 1999, Henare et al. 2007) it may seem preposterous to claim that something is missing. Nevertheless, it is time to go further in the "back to the things themselves" move. Even though Husserl's analysis of the relations between consciousness and reality has been greatly extended and enriched by dozens of theoretical and empirical studies, the focus remains on things for human beings. Up to now artifacts have been explored for what they mean for humans, how they mediate our relations to the world. Accordingly, technology studies have been focused primarily on the co-shaping of objects and users or on the ethical, social and political meanings and impacts of artifacts. A narrow understanding of this topic is instantiated in the institutionalized approach - under the acronym $\mathrm{ELSI}^{1}$ - to monitor the development of emerging technologies such as genomics, nanotechnology and converging technologies. However, the emphasis on the social, cultural, metaphysical and political dimensions of artifacts does not really take into account their temporality. As hybrids of nature and artifice, technical objects are not only carriers of human projects and values, they are also integral parts of natural cycles. They come into being through the use and the transformation of natural resources, and they endure in the world far beyond the limits of their existence as commodities. They have a history of their own.

Even Dutch philosopher Peter Paul Verbeek, who initiated a remarkable thing turn in "What things do," (Verbeek 2005) had the limited ambition to do justice to the concrete presence of technological artifacts in our culture. He is concerned with what things do to us rather than to the world we inhabit with them. His attempt at thinking from the perspective of things is purposefully characterized as "post-phenomenological" (Verbeek 2006; 2008) because, in his view, things are vital for elucidating our relations to the world. In this perspective the relation between human beings and their world takes centre stage, and are viewed as mutually constituting each other - human beings are what they are thanks to the ways in which they are present to the world, and their world is what it is thanks to how it appears to them (Verbeek 2005: 235).

\footnotetext{
${ }^{1}$ For "Ethical, Legal land Societal Implications/Impacts."
} 
Things essentially play the role of mediators between human beings and their environment. The major matter of concern regarding temporality is our experience of time in relation to technological innovation. This overly anthropocentric perspective has prompted a huge amount of scholarship devoted to the mutual shaping of new technologies and the tempo of life in modern societies. In addition to the cult of speed linked to transportation and communication technologies, digitalization has created a culture of instantaneity and immediacy (Castells 1996). Social theorist Harmut Rosa finally describes a three-fold process of acceleration, including technology, social change and the pace of life (Rosa 2013). He points out a paradox: Technological innovations were supposed to spare our time but we are increasingly under time pressure. Rosa concludes that technology no longer serves the "project of modernity," characterized since Habermas by the ideal of autonomy and emancipation. His analysis is congruent with the recent boom of "slow" movements - slow food, slow city, slow travel, slow design, slow money, slow school, slow books, slow science, slow trading, slow living - which express a rebellion against the disciplined clock-time imposed by capitalism and globalization. By contrast, Judy Wacjman (2014) diversifies the forms and sources of time constraints in her analysis of work patterns and domestic life. Although she acknowledges the evidence that technology did not alleviate time pressure, she argues that it is not just a matter of quantity but also of quality of time.

Whatever the high value and interest of the literature on acceleration, it remains focused on how technology has shaped our pattern and experience of time. Fully accomplishing the Copernican revolution in the philosophy of technology requires shifting the attention from humans towards the world that is to the complex made of the Earth with all things and living beings, including humans. This concept of world ignores the great divide between nature and society or culture (Latour 1991). In this worldly perspective, the thing turn means adopting the perspective of things and raising questions such as how artifacts come into being, how they intervene within the world, how they change it. Such issues are vital to prevent the alienation of technology both from nature and from human beings.

A number of philosophers have already discussed such questions. For instance, Gilbert Simondon's fine-grained analysis of the process of concretization of technical objects (1958) sheds light on their genesis and ontology apart from their utility for humans. Artifacts cease to be kept hidden and forgotten because of their handiness as soon as they are no longer described as tools for performing functions according to the plans of their designers. As they come into being through a process of concretization they acquire an ontological status in a human/nature world. Simondon went beyond a "facile humanism" by adopting an objectcentered perspective infused by the concept of technicity. Gilbert Hottois, on the other hand, used the concept of "operativity" in order to emphasize the intervention of artifacts upon the world. The philosophy of technology, he argued, requires more than hermeneutics because artifacts are not merely the result of an interpretation of the world, the sign of a representation; they actively contribute to shape and transform it (Hottois 1984).

As a way to go further into the investigation of the interplay between technology and the material world we share, this chapter focuses on the durability of artifacts. Though the notion of "sustainable development" has attracted a lot of public attention over the past decades, surprisingly few philosophers of technology did relate this concern to the ontological status of artifacts. Is it still the case that "the owl of Minerva spreads its wings only with the falling of the dusk"? In fact, philosophers did address this issue albeit not at the ontological level. They mainly discuss it in terms of environmental ethics. In keeping with the prevalent meaning of "sustainability", environmental ethics is mainly concerned with the Earth capacity to support human life and thus ironically favors an anthropocentric perspective. (Larrère and Larrère 2015) By contrast, the notion of durability, emphasizing the permanence and the endurance of artifacts, has the potential to open up a de-centered perspective. While R\&D practitioners, 
designers and engineers routinely perform life-cycle analyses and spread concepts such as "cradle-to-cradle" design, what do philosophers have to say about the durability of artifacts? In this chapter, the durability of artifacts is presented as a key issue that brings about a deep revision of their ontological status. I first argue that artifacts have no ultimate essence and have instead various modes of existence inscribing them in various histories and temporalities. Then, looking more precisely at the durability of two kinds of artifacts plastics and nuclear waste - I will discuss whether they confront us with a wide range of orders of magnitude or with more complex issues of incommensurable regimes of temporality.

\section{Prelude: Metaphysics}

In a famous article of his Principles of Philosophy, Descartes clearly stated that he didn't "recognize any difference between artisan-made machines and the various bodies that nature alone composes." (Descartes 1641: IV §203) More concerned with the understanding of nature than with the status of artifacts, Descartes assumed that the visible mechanisms at work in machines provide a model for understanding the invisible mechanisms at work in nature. He thus firmly rejected the ontological distinction established by scholastic philosophers who claimed that natural things unlike artifacts had an intrinsic "substantial form." For Descartes, machines are neither "against-nature" nor supernatural (magic). They are ruled by the laws of nature: "And anyway all the rules of mechanics belong to physics, so that all the things that are artificial are with that [avec cela] natural." My literal translation of this sentence is meant to emphasize that artifacts might not entirely be identified with natural things, they could rather have a dual status: They are artificial things besides being natural ones. There is no alternative, no either/or choice. And since technology is based on natural laws, improving technology and better understanding nature are one and the same objective. Physics will "thereby make ourselves, as it were, the lords and masters of nature." (Descartes 1637: VI, 44) The rapprochement between the artificial and the natural secures and legitimizes the domination of nature by humans.

On the other hand, Descartes (1664: 36) drew a clear boundary between objects and subjects. Nature being reduced to matter - i.e. to the res extensa - is ontologically distinguished from the res cogitans, proper to subjects. His metaphysics reinforced the distinction assumed in Roman law between persons and things and prefigured Kant's moral claim that human persons must be treated as ends and never only as means. The social contract, ethics and politics, are disconnected from nature. (Serres 1990) The "great divide" between nature and society, which prompted the institution of humanities and social sciences as an independent culture, is a chief characteristic of modernity (Latour 1999).

One major instantiation of this divide is the instauration of universal time. Although initially based on a natural cycle (the duration of the tropical year), it is a pure convention answering a joint demand from science and capitalism. This abstract meantime resulting from a process of averaging the length of solar day, ignores the variable cycles of daylight in order to create regular clock hours. The social clock time has nevertheless become so naturalized that natural rhythms dependent on local environment and biology become like disruptive anomalies. (Birth 2012) Living in a modern world thus means tacitly assuming that we are (increasingly) emancipated from nature and belong to culture and society.

\section{Entangled histories of plastics}

Synthetic polymers have gradually replaced glass, wood, and metal in many commodities. Plastic bags, bottles, pipes, pens, phones, computers, rackets are everywhere around us. Plastic materials are so familiar that we no longer wonder about their capability to take on multiple forms and be used in all sorts of applications. Thanks to the flexibility of carbon 
atoms, and their ability to form bonds with other atoms in whatever direction, especially strong covalent bonds that make up long chains or macromolecules, a great variety of materials can be synthesized. Many types of synthetic polymers, each one with a variety of different formulations have been manufactured and commercialized. One of their advantages is that they can be synthesized and shaped simultaneously. Polymerization and molding, matter and form are generated in one single operation. Moreover, during this dual process it is possible to include various additives, such as plasticizers or reinforcing fibers in order to obtain specific properties and functionalities. The design of composites materials has expanded the market of plastics and secured the success and wealth of the petrochemical industry.

Despite the commercials advertising plastic items - Tupperware for instance - as icons of modern life in the 1950s, "plastics have never been modern." In Bruno Latour's sense (1991), they intermingle what modern philosophers struggled to clearly separate. When synthetic polymers replaced or displaced conventional materials in many applications, the phrase "Plastic Age" has been coined to suggest the advent of a new cultural era, comparable to the iron-age in the past. The mass consumption of plastics did actually spread the NorthAmerican lifestyle and values all over the world (Sklar 1970; Meikle 1995). As Roland Barthes (1957) argued in his review of the mythologies of modernity, plastics connote the magic of indefinite metamorphoses. Whereas gold or diamond conveys a view of permanency and eternal faith, plastics epitomize the ephemeral, the ever changing. They are so light that they lose their substance, their materiality, to become almost virtual reality. As they are malleable and indefinitely adaptable, they connote and spread such values as impermanence, flexibility, and superficiality through culture.

Plastics do have politics (Winner 1986) because of their material properties (Gabrys et al. 2013). They are not only value carriers; they also prescribe specific behaviors. Because they are cheap, light, and easily disposable, plastic bottles, cups, and syringes are specifically designed for one single use. Their normative power turns users of artifacts into consumers of disposable objects. Such consumerist behaviors often legitimized with hygienic rationales basically favor hedonistic inclinations to enjoying the present moment. They encourage a specific experience of time, as an instant detached from the flux of time, a discrete moment disconnected from the past and the future. Unlike Virginia Woolf's "moments of being" however, such instants do not go with flashes of awareness of the world around. Rather their iteration in daily routines generates a kind of protective screen-effect.

The mass consumption of plastics went on with a protective blindness concerning their whereabouts. Where do they come from, where do they go when we put them in the rubbish bin? Such trivial questions have the power to raise discomfort about our consumerist attitudes as well as ontological issues. An ontogenetic perspective on plastic objects subverts both the modern dichotomy between nature and politics and the Cartesian view of nature. Try to follow the trajectory of plastic items, and suddenly food, chemistry, children, geopolitics, become entangled with the history of technology, of capitalism, and of the Earth (Mariott and Minio-Palluello 2013). ${ }^{2}$ The journey of a mundane artifact such as a plastic food container provides a rich narrative bringing together the depletion of resources, the conflicts between

\footnotetext{
${ }^{2}$ In a paper presented during a Conference on Plastic accumulation at University of London, James Mariott offered ice cream cornets to the audience and then started telling stories about the ice cream container left empty on the stage. On Google map he followed the trajectory of this little plastic tub manufactured by a chemical corporation listed on Stock Exchange, from the oil drill in Azerbaijan through pipelines, big tankers cruising the ocean, to the European factory, the supermarket and finally the British building where the plastic container which satisfies our appetite for ice cream would be placed in the rubbish containers and picked up by a garbage truck to a recycling station.
} 
the North and South, social unrest, the accumulation of capital in the hands of a few multinational companies, and the accumulation of plastic garbage everywhere...

The travel through space of plastic objects is also a travel through time. More precisely, the story of their pre-life and post-life intertwines many different times. Most of the 260 millions of tons of plastics annually commercialized are made out of fossil fuels, so that they irreversibly consume the results of the spontaneous degradation of organic materials, which settled in the rocks 3.4 millions of years ago. Their existence of a few days or months as disposable commodities contrasts with the geological times involved in their previous existence. The four per cent of the world's oil bound to become plastic materials start new lives under the sun. After extraction, transportation, and transformation the fossils first exist as small granules made from oil and a cocktail of additives. Those resin pellets manufactured by petrochemical companies will then be melted and molded in plastic artifacts, although some of them being lost during transport or in the manufacturing site continue their granular existence among the sand of the beaches or floating on seawater and carried by streams. The ephemeral character of plastic commodities is even more delusory if we consider the accumulation of plastic detritus everywhere in the countryside and in the ocean. The nice, bright and colorful plastic toys or gadgets that we trash after one single use end up in a grand garbage patch of thousands of square meters. The micro-balls charged with highly concentrated persistent organic pollutants accumulated in the oceans since World War II create a "plastic soup," which deeply affects the biosphere of marine creatures (Gabrys 2013). Here is the irony of the Plastic Age. The cult of impermanence and change that distinguished it rests on a deliberate blindness regarding the material condition of plastic items. These attractive objects, apparently liberated from the constraints of materiality, from gravitation and duration, are enduring. Their ephemeral existence is just the tip of an iceberg of memory. It is the upper layer of many layers of plankton buried in the seafloor or in the rocks for millions of years and it is only a small fraction of the complex biochemical and metabolic processes that constitute the carbon cycle. The brief existence of plastic artifacts as commodities is nothing but an instant abstracted from the long duration of material processes on Earth.

More importantly, the life story of any plastic object clearly demonstrates that materials have a say in what they become. On the one hand, carbon macromolecules with their bonding capacities afforded the Plastic Age, i.e. the substitution of wood, metals for plastics in most commodities. Because synthetic polymers are lighter and more malleable than the materials they displaced they have encouraged the dream of dematerialized technology. (Bensaude Vincent 2013). But the plastic items that served our desire and economy do not magically disappear from the planet when get rid of them. They just disappear from our sight being shipped far away to Southern countries for complex operations of recycling with the help of toxic chemicals and cheap manpower or simply incinerated in a nearby urban power station to produce heat. Plastic toys and attractive gadgets are congealed in the eternal present of our desires, detached from their own histories, from the material world with its complex cycles of transformation as well as from the contingencies of market and fashion. Aggressive advertising campaigns presenting plastics as a cornucopia coupled with cynic strategies of programmed obsolescence have encouraged the accumulation of capital in chemical companies together with an active ignorance among consumers. (Proctor and Schiebinger 2008). Such market strategies conceal that commodities are things with a life of their own, which interact with many lives around. Like all creatures in the world they are ageing, they need care and maintenance. The cult of innovation and invention leads to disregard the significance of repair and maintenance (Edgerton 2007). Technical objects are not reducible to the functions and services that they perform for us. As soon as they come into being they interact with a wide range of beings that populate the world and not just with us. 
De-commodifying plastic items to objectify them is a necessary first step as long as the process of commodification of objects goes with a "genesis amnesia" cutting its products from their own past and future (West-Pavlov 2013: 128). Yet, as we will see, this is only a preliminary step.

\section{Interlude: Ontography}

The life of plastic objects confirms that the rigid boundary between nature and society is no more robust than the boundary between nature and artifact. Such ontological divides proceed from a sub specie aeternitatis metaphysics looking for the essence of things instead of considering their genesis and becoming. Even though plastics epitomize the artificial and have the dubious reputation of being unnatural qua synthetic they participate in the whole process of the natura naturans. Therefore an ontographical approach to artifacts may be appropriate. Why substitute the suffix "logy" for "graphy?" Just as ethnography refers to a simple descriptive report of field inquiry without any attempt at systematizing or theorizing, an ontography follows its objects and describes their trajectories. Ontography has first been promoted by Michael Lynch (2008) in keeping with the social studies of science purpose of dismantling the grand metaphysical schemes in favour of empirical case studies. "Deflating ontology" was just one side of the coin; the other one was to turn "matters of fact" into "matters of concern" by looking at how things are framed as nodes in a network of material, political, economic and legal actors. Ontography in this sense emphasizes the heterogeneous ingredients that converge in the coming into being of technical objects. ${ }^{3}$

In this essay the ontographical approach is meant to support two major claims. ${ }^{4}$ First, the question about beings does not concern what lies beneath them (sub-stance) or behind the appearance. As an attempt to identify the modes of existence of individual entities, ontography does not assume that they are deducible from other entities through a causal chain. Nor does it presuppose any hierarchy of levels of beings. Ontography pays attention to the multiple ways of being, to the variety of "modes of existence" and thus moves beyond the dilemma between realism and constructivism. Etienne Souriau (1943) promoted a "multirealism" and Latour (2013) talks of the "pluriverse." The concept of "modes of existence" not only gets rid of the either/or categories and emphasizes the plurality of ways of being but it also points to the connections between various events or actions like the grammatical modes expressed by inflections of verbs.

Second, while the logos (in ontology) clearly refers to analytical and argumentative discourse, the reference to graphein (in ontography) means that narration is a relevant and penetrating form of discourse about things. Telling stories is a way of emphasizing the temporal dimensions of things. The plot displays the complex threads that have to be intertwined for things to come into being and then to endure into existence. Storytelling - whether it be in the form of a chronicle, a biography, a fiction, a drama, a fable or mythological tale - helps replacing the Kantian concern with the "constitution" of things by Souriau's notion of "instauration." (Souriau 1939) Instead of asking about the conditions of possibility of artifacts, let us look at how they come into being through contingent events and in the course of actions. The resilience and obduracy of artifacts, their inscription in biological, geological

\footnotetext{
${ }^{3}$ Graham Harman's ontography is a more ambitious attempt at promoting an alternative ontology centred on objects, and displaying the relationships between objects. The suffix "graphy" refers to a graphical representation of all the possible relations between what he considers as the four basic poles of reality (real objects, real qualities, sensual objects, sensual qualities). "Rather than a geography dealing with stock natural characters such as forests and lakes, ontography maps the basic landmarks and fault lines in the universe of objects." (Harman 2010: 125) Far from favoring a strictly descriptive approach to objects Graham promotes a "speculative realism" claiming that objects are not reducible to relations and that individual entities of various different scales are the ultimate stuff of the cosmos.

${ }^{4}$ This ontographical approach is instantiated in Sacha Loeve and Bernadette Bensaude Vincent (2017).
} 
cycles and their interference with far wider cosmic process is certainly something that a conventional philosophical argumentation can express. Yet narratives provide a much thicker description of how particular things stand in the world, how they hold the place, resist and oblige humans to care for them.

\section{The Perdurance of Nuclear Waste}

In the post-war era, France has massively invested in nuclear power through a close alliance of military and civil goals with a view to assert its autarchy thanks to its own technology (gasgraphite reactors) and the uranium resources from its colonies (Hecht 1998). In the 1970s, following the first oil crisis and environmental alarms France decided to rely on nuclear technology for its supply of electricity. It resulted in the construction of 58 nuclear reactors, which today produce $73 \%$ of the electrical power consumed in France. This national choice meant to reduce the dependence from petroleum exporting countries has the additional advantage of reducing the emissions of greenhouse gas. To fuel the reactors the mining business group Areva is in charge of the exploration, extraction, and refining process of the uranium ores, with long-term contracts signed with mining companies especially in Africa. The French nuclear order thus maintains a colonial geopolitical regime (Hecht 2012). We will see that the materiality of nuclear combustibles and reactors also generates a clash of temporalities.

Nuclear plants are rather short-lived while the residues of their productive activities are extremely long-lived. The fission products of the uranium dioxide (UOX) loaded in the reactors are so radioactive that they can cause damage to all living things and will remain dangerous for a long time. According to the law of radioactive decay, the half-life of nuclides of actinides (hundred thousands years) is so out of proportion with the timescale of human life and of democratic regimes (5 to 10 years) that it far exceeds our capacities for anticipation and imagination. And the question of nuclear waste is a hot topic raising embarrassment and public protests.

What can be the life of the tons of dangerous waste produced year after year by nuclear reactors? It is difficult to figure out. Let us follow the trajectory of these undesirable residues thanks to an inquiry conducted by Laurence Raineau (2012) and Sophie Poirot-Delpech (2017). The assembly metal rods of used fuel extracted from the reactor are first let to cooldown near the nuclear plant for a few years. They are then packaged in huge containers of 110 tons each and trucked to La Hague, in Normandy, for further cooling underwater. Since the used fuels still contain a good proportion of uranium and plutonium and highly radioactive nuclides of actinides, technological solutions have been implemented for recycling them. ${ }^{5}$ However, reprocessing means that hazardous radioactive materials are handled and trucked through the country, in secret convoys to avoid publicity since plutonium is an ideal material for nuclear weapon. In addition, the attempt to close the fuel cycle cannot be successful because the fuel can be recycled only once before final disposal.

Ultimate waste, referred to as radioactive substances "for which no further utilization is predicted or envisaged" are more than toxic than the earlier ones. They are bound to spend at least the next hundred years in small packages buried in a 500 meter-deep cavern of $30 \mathrm{~km}^{2}$. The project of containment of final waste in an Industrial Centre for Geological Storage (CIGEO) located in the North-East part of France conducted by the National Agency for the Management of Nuclear Waste (ANDRA) is well under way. It has been launched in 2000 following a decree (the 1991 Bataille Law) stipulating that the method of storage should allow

\footnotetext{
${ }^{5}$ First, a chemical treatment of the fission products separates uranium and plutonium from non-recyclable fission products. Second, the depleted uranium is enriched. Finally it is trucked again for being reprocessed in Southern nuclear facilities, which produce a new fuel (MOX) made of a mixture of depleted uranium and plutonium that will be used to fuel advanced nuclear reactors.
} 
the recovery of packages within 100 years. Although this measure testifies to a political awareness about the uncertainty of the future (Barthe 2006), it did not settle the question. The CIGEO project still raises public protests, and following a nationwide debate held in 2013, the opening of the industrial storage site has been simply postponed and research continues. (ANDRA 2014) To settle the noise and fury, the clock of political measures has been stopped, time frozen. Meanwhile the recalcitrant radionuclides carry on radiating and accumulating. They quietly "perdure". (Ingold 2013)

In many nuclear countries, people are desperately looking for reliable means for communicating with the future generations (400 generations for every 10.000 years) about the danger of nuclear waste sites (Galison 2010). The plans to turn storage sites into sanctuaries earnestly try to bridge the huge gulf between the lifetime of humans and that of decaying radionuclei. However, assuming that the root of the problem lies in the gap between the timescales of human history and radioactive decay, that it is just a question of orders of magnitude is still an over-simplistic view. Not only the sites of storage have local impacts on the biosphere by creating zones of exclusion for all forms of life, but also the accumulation of toxic waste is not sustainable. As long as the recycling of used fuel (MOX) and nuclear reactors based on fusion (still investigated in the megaproject of International Thermonuclear Experimental Reactor - ITER) are not working successfully, nuclear energy cannot be a renewable source of energy. Clearly, reversibility and renewability are keys to sustainability but radioactive decay is a spontaneous and logarithmic process, which resists all attempts to close the cycle.

Here is a major ontological difference between plastic waste and nuclear waste. Most synthetic polymers do not biodegrade but they are photodegradable, so that plastic debris are are extremely small, mobile and pervasive. Tiny fragments of plastics are to be found everywhere on the planet. They float randomly in the oceans, thus making a "plastic soup". They occasionally melt with volcanic rocks to form 'plastiglomerates' such as the ones found in 2013 on Kamilo Beach in Hawaiii. (Corocan et al. 2014) This agglomerate of natural rock and artefacts epitomize the anthropogenic imprint on geology. Plastics have been seriously considered as serious candidate markers of the beginning of the Anthropocene by geologists. (Zalasiewicz et al. 2016) Yet ultimately they decided that radionuclides would make better markers. Indeed radioactive materials, unlike plastic materials, have a statistically predictable behavior: as soon as their isotopic composition is determined their half-life is known. It does not mean that nuclear waste better fit in nature, for that matter. Even more than plastic debris they are endurable, recalcitrant and irreversible. Some plastic bottles can be recycled even though the process consumes energy and produces toxic waste, in turn. In addition, plastic debris floating in the ocean end up eaten by marine creatures. They become food for bacteria, plankton, and fish. Synthetic polymers with their toxic additives finally enter the food chain of marine creatures and the skeleton of the macromolecules starts a new existence within the biological carbon cycle thanks to microorganisms acting as silent and invisible "carbon workers." (Gabrys 2013). Whereas plastic waste create a major environmental problem because they spread toxic materials in living beings, nuclear waste are not edible, not compatible with living creatures. And even if extremophile synthetic bacteria were convinced to "eat" them, they would not dispose of their radioactive properties. Radioactive materials hold the place for ages and will still keep it after the extinction of mankind.

Disposable plastics and irreversible nuclear waste help identify the prerequisites for sustainable technologies. Technical objects have to be both durable and degradable. Hannah Arendt grasped the fine-tuned temporal condition of technical objects in her analysis of the vita activa with its three categories of labor, work and action. She emphasized that artifacts endure in existence after the production process and long after their uses in human societies, thus securing the "reality and reliability of the human world." (Arendt 1958: 95) The 
durability of artifacts plays a key role to overcome the limited lifespan of humans; it stabilizes society and the public sphere of action. However, Arendt never assumed the irreversibility of technological processes:

This great reliability of work is reflected in that the fabrication process, unlike action, is not irreversible: every thing produced by human hands can be destroyed by them, and no use object is so urgently needed in the life process that its maker cannot survive and afford its destruction. Homo faber is indeed a lord and master, not only because he is the master or has set himself up as the master of all nature but because he is master of himself and his doings. (Arendt 1958: 144)

The notion of mastery inherent in the Cartesian view of technology collapses under the overwhelming evidence of the irreversibility of the products of our most brilliant technological achievements. "How can we dominate our domination; how can we master our own mastery?" For Michel Serres this pressing question results from the completion of the Cartesian project (Serres 1992: 251). Since we have become masters of space, of matter and of life, there is nothing left on Earth that does not depend on us. It is no longer possible to draw a boundary between the things that do not depend on us - natural phenomena - and those that depend on us (local and political matters). The comfortable divide underlying modernity between the "inexorable necessity" of nature and the realm of action (ethics and politics) seems to fade away.

The lives and actions of our children soon will be conditioned in fact by an Earth that we will have programmed, decided upon, produced and modeled. [...] In the future we will live only under the conditions that we will have produced. (Serres and Latour 1995: 174)

Increased technologization and socialization of nature seems to be our destiny. The arrow of time reinforced by the common assumption of an exponential growth of information technologies as expressed by the famous Moore's law is supposed to dictate our future (Loeve 2015).

However, the arrow of time is a socio-historical construction, which has accompanied the modern ideal of mastery of nature and may consequently be questioned together with this ideal. To what extent is it possible to take into account the times of nature, to favor a model of softer technology working with nature instead of upon her or against her? (Larrère and Larrère 2015) And what metaphysics of time would replace the standard arrow of progress?

\section{Conflicting Regimes of Temporalities}

In 1971, US biologist and pioneer of the environmental movement Barry Commoner published an ambitious essay entitled Closing the Circle. Man, Technology and Nature, which turned out to be a bestseller. Unlike Rachel Carlson's Silent Spring (1962) Commoner did not use a poetic fable to raise public awareness about the environmental damages caused by chemical technology. He promoted ecology as the "science of planetary housekeeping". With this reference to the Greek term oikos (house, family) Commoner clearly regarded nature as home for humans. While maintaining a human-centered perspective, he nevertheless clearly pointed out a discrepancy between the cycles of nature and the linear time of technology:

Stich ecological cycles are hard to fit into the human experience in the age of technology, where machine A always yield product $\mathrm{B}$, and product $\mathrm{B}$ once used, is cast away, having no further meaning for the machine, the product, or the user. (Commoner 1971: 4)

For Commoner the divorce between our experience of time and nature is not due to the proliferation of innovations and the subsequent acceleration of life. It is not just a question of pace, of tempo; it is a question of meaning. In the linear model of technological production, the by-products of manufacturing process are meaningless. Like the caput mortuum of alchemists, they are worthless remains to be disposed of. In natural processes, by contrast, there is no caput mortuum, no waste. Everything is degraded and the building blocks entering into new combinations go through new adventures. The linear time of technology and the 
arrow of time epitomizing technological progress do not fit well in the cycles of nature. Concerned environmental activists have thus highlighted a fundamental discrepancy of regimes of temporality, and subsequently prompted efforts to introduce "cycle thinking" (from cradle-to-cradle) in technological innovation, through bio-inspiration. Over the past decades such efforts and campaigns have yielded a number of innovating biomimetic processes and products for promoting green chemistry as well as ecomimetic agriculture reconnecting farmers and nature. Bioeconomy - an economy based on renewable biological processes and products - is celebrated as the avenue to sustainable development (Passet 1992). The key is to insert our technological interventions within the dynamics of nature, to take advantage of spontaneous phenomena of self-organization and self-regulation. Although the bioeconomy agenda turned out to maintain the Cartesian ideal of mastering nature when it implies redesigning life and manufacturing synthetic organisms, it rests on the monitoring of natural processes and has to comply with natural cycles.

By contrast, another clash of temporalities has gained traction recently through the emergence and dissemination of the notion of Anthropocene. (See Stewart, this volume). In two hundred years since the industrial revolution humans have consumed fossil resources that had been stored for 3.800000 years in the soil, thus releasing a huge amount of carbon dioxide in the atmosphere. In other terms, it is a kind of "tempophagy" - time eating. (Cohen 2012) With the massive emission of greenhouse gases mankind has bridged the gulf between many orders of magnitude. The Anthropocene blurs the boundary between social history and natural history, and as such it could mark the end of modernity (Latour 2014).

Yet underlying this notion is the modern assumption of a timeline running from the Big Bang (15 billion years) to the apparition of life on the planet ( 4 millions years) and the history of civilization (6000 years) - a unique global time described in powers of ten. To convey a view of the gap between the powers of ten, science writers use metaphors such as the cosmic year (with humans appearing in the last second on December 31) or the week of Genesis; all of them converge on human history as though mankind were the telos of the existence of Earth. Unsurprisingly the narratives of the Anthropocene provide a rationale for geo-engineering projects. As the intensification of human pressure on the planet has caused damages, it seems legitimate to extend human intervention to the world itself in order to fix it. This strategy of fighting fire with fire only makes sense in the modern worldview of humans as masters of the Earth and progress as emancipation from nature, from space and time constraints.

In the narratives of the Anthropocene, the clash of temporalities resulting from human technology is seen as a quantitative difference in orders of magnitude, a leap over timescales due to the acceleration of technological power, whereas the conflict between the vector of economic growth and the cyclic time of nature is a central pillar in environmentalist movements.

\section{From Timescales to Timescapes}

How are we to understand the increasing concern with the clash of temporalities? Is it the result of the acceleration of technological innovations or the symptom of a more radical heterogeneity of regimes of temporality that calls for a deep revision of our metaphysics of time as well as of our technological practices?

The narratives of the Anthropocene do not challenge the dominant view of a global time as a universal container, which measures the existence of all beings. They even reinforce the significance of the timeline for enhancing the wide spectrum of timescales. This linear view of a global time that we take for granted is nevertheless a social convention resulting from a mixture of various ingredients: natural phenomena (from the course of celestial bodies to a specific radiation of cesium atom), technical objects (calendars and clocks), scientific concerns (precision measurement, normalization) and economic pressure (disciplining labor 
in industrial capitalism) (Birth 2012). The result is an abstraction, a time detached from all localities as well as from our social time (Nowotny 1994). A time viewed from nowhere. Universal time is a powerful tool ensuring the commensurability of everything so that the cycles of nature can be dutifully located in periods of geological time (Archer 2004). The heterogeneity between the cyclic regime of temporality and the linear regime is dissolved in the powers of ten.

However, reconciling the cycles of nature with our immoderate fondness for timelines is only one aspect of the issue of durable technology. The two conflicting regimes of temporality highlighted by environmental activists give a partial view on the heterogeneity of times involved in technology. Their narrative does not question the prevailing metaphysical framework since it remains focused on the polarity between humans and nature. In order to implement more durable technologies, it is necessary to pay attention to local timescapes rather than relying on a global survey of timescales (Adam 1998). Shifting from a global to a local perspective, looking at the crowd of agencies that inhabit the world is key to realize that everyone has its immanent temporal regime. We have to combine Michel Serres's philosophy of things with Gilles Deleuze's neo-Bergsonian metaphysics of time.

Deleuze (1980) developed a critical analysis of the notion of a metric time, of an objective linear time divided up into identical instants within which events would take place without affecting their container. He suggested multiple overlapping flows of time without any transcendent time embracing the multiplicity of times and things. If we consider time as process rather than as a universal container, things are adequately described as a constant flux time, a process of becoming. Things - whether natural or artificial - tell their times, thus delineating contingent histories. And there is no synchrony between the individual times displayed in the world of things. Together they form a strange patchwork with entangled loops and twists, a "meshwork" with knots and loose ends rather than a network with nodes and connections (Deleuze and Guattari 1980; Ingold 2013). Their timelines are traces of movements and processes, similar to the lines left by waves on the waterfront or the traces left by moving slugs on the pavement.

Serres has paid a lot of attention to material things - to solids, fluids, gas and mixtures - and to their temporality. ${ }^{6}$ While focusing on the material basis of society and culture, Serres distinguishes things from objects, more precisely quasi-objects. Humans turn things into objects when they use them to settle social links and relations: quasi-objects, are relational, always passing from hand to hand like a rugby ball and thus creating a collective. Things by contrast belong to a more obscure face of the world. They are not reducible to their causes: "We can always go from the thing produced to its conditions but never from the latter to the former." (Serres 1977: 115) In Genesis, Serres tries to understand the emergence of things in the world without assuming the pre-established scheme of linear causality. Things come into being out of noise and disorder like a vortex in a turbulent flow that would be stabilized by repetition and redundancy. For instance, imagine that in a few minutes you could run the film of the formation of the coast of Brittany over million of years, you would see a flame. Things are like frozen pictures taken in a long process. In this respect, they are sites of memory, while being always in becoming.

In addition, Serres questions the divide between things and signs, between the hard and the soft. All things carry the marks of time while they are ageing and worn out.

\footnotetext{
${ }^{6}$ Like Arendt he emphasized the role of objects in society. "When we think society we need a good philosophy of objects." Objects provide stability to the social contract, thus regulating the pace of social history: "In fact, the object, specific to Hominidae, stabilizes our relationships, it slows down the time of our revolutions" (Serres, 1982: 87).
} 
Most objects are clocks [...] New harmful blow to human narcissism: everything in the world exchange information and store it. All bodies are engraved, like the Rosette stone or shits with graphics." (Serres 1977/2000: 217)

Material things speak and write for those who read and listen to them as Serres does in Biogée (2003). While "reading" living bodies, Serres insists on the multiple times embedded in them. Living things carry the memory of thousand years of life on earth in their DNA and at the same time, each of them opens up indefinite potentials of evolution.

With such philosophical resources we can move beyond the standard view of one single timeline with a scale of different orders of magnitude. "Scalism" is not sufficient to disentangle the complexity and contingency resulting from the interference of various figures of times. Just as a landscape is a composition of heterogeneous elements, a timescape is a composite of heterogeneous regimes of time (Adam 2004). Aside the cycle and the timeline many other forms of time are to be found: vectors, spirals, trees, strata, rhizomes and meandering rivers.... In timescapes the boundaries between natural beings and artifacts are blurred. They are all composites of various materials - flesh and bones, matrix and fibers, etc. - each one with their individual lifetimes.

Not only time is immanent to the life of every being (West-Pavlov 2013), but each habitant of the world - from volcanoes to microbes - is a nest of different times, with internal clocks. For instance, bacteria have been favorite model organisms for laboratory research because of their reproduction rate $(20 \mathrm{mn}$ in average). Today re-engineered bacteria are used as factories to synthesize drugs or even materials such as artificial spider silk. As we re-engineer these living beings for our manufacturing purposes we overlook that their capability to perform works of interest for us, are the outcome of a long and contingent history of several millions years. While we are messing up with their own temporalities, we neglect their collective capacity of enduring in the world through mutations and adaptations to the most extreme conditions by inventing new regimes of temporality. In instrumentalizing bacteria as laboratory models because of their fast reproduction rate, in re-engineering them as tools or factories we neglect their incredible evolutionary potentials in the mid and long term. We are so focused on our time, that we tend to believe that the process of evolution would be magically erased by our project of redesigning bacteria.

\section{Coda: Ethics}

Over the past decades ethics, has become a chaperon of all research projects with a view to promote "responsible research and innovation." Ethical committees are created in research institutions to assess the compatibility of innovations with core values. Social scientists introduced upstream have to stay on board in order to anticipate the ethical, legal and societal impacts of the future technological applications.

With the kind of ethics promoted as the mandatory partner of technological innovation there is no chance to break up the arrow of time. Quite the contrary, anticipatory exercises often turn out to colonize the future, by imposing on the future generations our present standards and values. Moreover, the calls for responsible innovation are still based on the modern ideal of man in control and mastery of nature, while in our view renouncing the central position of humans and the divide between persons and things is a precondition for trying to promote a more adequate ethics of technological innovation.

Being aware of the "polychrony" of things is a safe way for promoting "responsible" technologies. It is primarily a way of preventing risks and anticipating potential disasters without adopting a techno-optimistic attitude or a catastrophist perspective. No need to anticipate the disaster, to make the future present, in order to avoid it. Jean-Pierre Dupuy's "enlightened catastrophism" (2004) turns the arrow of time upside-down but sticks to a linear "monochronic" view. 
However, polychrony does not call for an ethics of responsibility. It rather provides a sound base for an ethics of attention to the propensity of things. In considering them as archives of a long history, we could be more respectful of them and more concerned about their maintenance and about their future. Telling the life-story of technical objects is a way to considering them as co-actors or partners who share the world with us.

An ethics and aesthetics of immanent temporalities would acknowledge the primacy of the agency and existence of all entities as the forward-moving dynamic of time itself. Such an ethics and an aesthetics would radically displace humanity as the central actor in the natural global economy, inculcating a new respect for other beings and things as co-actants, thereby contributing to an alternative ecology and oekonomy (in the etymological sense of management of resources) of the global system. (West-Pavlov 2013, p.122)

As Deleuze argued in his lectures on Spinoza, ethics, in contrast to morality, is closely related to ontology. Rather than "judging" actions in the name of transcendent or universal values, ethics, just like ethology, is concerned with ways of being and behaving (Deleuze 1980). Far from assuming a qualitative difference of essence between persons, animals, and things ethics determines the capabilities of every being according to their potentials (puissance). Camels are capable of surviving a few days without drinking, diamond is capable of cutting glass. Ethics is concerned with what things can do rather than what we must do. Technology assessment requires that we turn our attention to the register of capabilities of all things and consequently to the various times immanent in them.

\section{Conclusion}

Based on empirical studies of a sample of recent technical objects and an acquaintance with the works of Simondon, Serres and Deleuze, this chapter advocates a deep revision of our metaphysics as a condition to promote more durable technologies. The mass production of disposable items like plastics has reduced artifacts to utilities and commodities meant for consumption in discrete instants detached from the continuity of duration. The mass production of radioactive nuclides in final nuclear waste confronts us with a long duration that far exceeds our potentials of imagination and anticipation. As an alternative to the hubris underlying the Promethean sociotechnical imaginary attached to the arrow of technological progress, the environmental paradigm invites to reconciling the arrow of time with the cycles of nature. Mimicking nature or at least designing technical objects more integrated in natural cycles of nature is indeed a necessary - and still desirable - step, but it is only a small step. In order to move forward, the very notion of one universal transcendental timeline embracing all things and events needs to be questioned. While this framework proved remarkably powerful to increase our scientific knowledge of the world, it is not adequate to technological knowledge and action. Paying attention to the multiple times embedded in things and to the interplays of regimes of temporalities in all technological project is a precondition for constructing a common and durable world, shared by all sorts of beings.

\section{Acknowledgements}

A preliminary version of this text has been discussed by Astrid Schwarz and Jean-Paul Karsenty during the authors' workshop held in Paris Sorbonne on 22-23 June 2015 in view of the preparation of the collective book.

\section{References}

Adam, B. (1998). Timescapes of Modernity: The Environment and Invisible Hazards. London: Routledge. Adam, B. (2004). Time. Cambridge, MA: Cambridge Polity Press.

ANDRA (2014). Le débat public Cigeo. http://www.cigéo.com/le-debat-public. Accessed 31 July 2016. Archer, D. (2004). The Global Carbon Cycle. Princeton, NJ: Princeton University Press. 
Arendt, H. (1958). The human condition. Chicago, IL: University of Chicago Press. (1998 edition). Chicago, IL: University of Chicago Press.

Barthe, Y. (2006). Le pouvoir d'indécision. La mise en politique des déchets nucléaires. Paris: Economica. Barthes, R. (1957). Mythologies. Paris: Seuil. English edition: Barthes, R. (1972). Mythologies (trans: Lavers, A.). New York: The Noonday Press.

Bensaude Vincent B. (2013). Plastics, materials and dreams of dematerialization » In J. Gabrys, G. Hawkins, \& M. Michael (Eds.), Accumulation. The Material Politics of Plastic (pp. 17-29). London: Routledge.

Birth, K. (2012). Objects of Time. How Things Shape Temporality. New York: Palgrave McMillan. Castells, M. (1996). The Rise of the Network Society. Oxford: Routledge.

Cohen T. ed. (2012) Telemorphosis: Theories in the Era of Climate Change, vol. 1, Ann Harbour, Open Humanity Press.

Commoner, B. (1971). The Circle Closing. Nature, Man and Technology. New York: Alfred A. Knopf Inc. Corocan P., Moore C.J., Jazvac K. (2014) An anthropogenic marker horizon in the future rock record, Geological Society of America Today, June 2014, pp. 4-8.

Deleuze, G. (1980). Cours à l'Université de Vincennes-Saint-Denis, December 9, 1980 http://www2.univparis8.fr/deleuze/article.php3?id article=137. Accessed 31 July 2016.

Deleuze, G., \& Guattari, F. (1980). Mille plateaux. Paris: Editions de minuit. English edition: Deleuze, G., \& Guattari, F. (1987). A Thousand Plateaux (Trans: Massumi, B.). Minneapolis, MN: Minnesota University Press. Descartes, R. (1637). Discours de la méthode. In R. Descartes, Euvres vol. I. Paris: Adam et Tannery. English edition: Descartes, R. (1999). Discourse on Method and Mediations in First Philosophy (trans: Cress, D. A.). Indianapolis and Cambridge: Hackett Publishing Co.

Descartes, R. (1641). Principes de philosophie. In R. Descartes, Euvres. Paris: Adam et Tannery, vol. IX. Descartes, R. (1664). Le Monde. In R. Descartes, Euvres. Paris: Adam et Tannery, vol. XI.

Dupuy, J.-P. (2004). Pour un catastrophisme éclairé. Paris: Seuil.

Edgerton, D. (2007). The Shock of the Old: Technology in Global History. Oxford: Oxford University Press. Gabrys, J. (2013). Plastics and the work of the biodegradable. In J. Gabrys, G. Hawkins, \& M. Michael (Eds.), Accumulation. The Material Politics of Plastic (pp. 208-227). London: Routledge.

Gabrys, J., Hawkins G., \& Michael, M. Eds. (2013). Accumulation. The Material Politics of Plastic. London: Routledge.

Galison, P. (2010). Underground Future. In M. Mostafavi, \& G. Doherty (Eds.), Ecological urbanism (pp. 304305). Baden: Lars Müller Publishers.

Harman, G. (2010). Towards Speculative Realism: Essays and Lectures. New York: Zero Books. Henare, A., Holbraad, M., \& Wastell, S. Eds. (2007). Thinking through things. Theorising artifacts ethnographically. New York: Routledge.

Hecht, G. (1998). The Radiance of France, Nuclear Power and National identity After World War II ( $2^{\text {nd }}$ edition 2009). Cambridge, MA: MIT Press.

Hecht, G. (2012). Being Nuclear. Africans and the Global Uranium Trade. Cambridge, MA: MIT Press. Hottois, G. (1984). Le signe et la technique, La philosophie à l'épreuve de la technique. Paris: Aubier. Ingold, T. (2013). Making Anthropology, Archeology, Art and Architecture. London: Routledge.

Latour, B. (1991). Nous n'avons jamais été modernes. Essai d'anthropologie symétrique. Paris: La Découverte. English edition: Latour, B. (1993). We Have Never Been Modern (trans: Porter, C.). Cambridge, MA: Harvard University Press.

Latour, B. (1999). Politiques de la nature; Comment faire entrer les sciences en démocratie. Paris: La Découverte. English edition: B. Latour, B. (2004). Politics of Nature. How to Bring the Sciences into Democracy (trans: Porter, C.). Cambridge, MA: Harvard University Press.

Latour, B. (2012). Enquête sur les modes d'existence. Une anthropologie des Modernes. Paris: La découverte. English edition: Latour, B. (2013). An Inquiry into Modes of Existence. An Anthropology of the Moderns (trans: Porter, C.). Cambridge, MA: Harvard University Press.

Latour, B. (2013). Facing Gaia. A New Inquiry in Natural Religion. Edinburgh: Gifford Lectures 2013. http://www.bruno-latour.fr/sites/default/files/downloads/GIFFORD-BROCHURE-1.pdf. Accessed 31 July 2016. Loeve, S. (2015). La Loi de Moore. Enquête critique sur l'économie d'une promesse. In M. Audétat, G. Barazzetti, G. Dorthe, C. Joseph, A. Kaufmann, \& D. Vinck (Eds.), Sciences et technologies émergentes: Pourquoi tant de promesses? (pp. 91-113). Paris: Hermann.

Loeve, S., \& Bensaude-Vincent, B. (2017). The Multiple Signatures of Carbon. In B. BensaudeVincent, S. Loeve, A. Nordmann, \& A. Schwarz (Eds.), Research Objects in their Technological Setting (pp. 185-200). Abington: Routledge.

Lynch, M. (2008). Ontography: Investigating the production of things, deflating ontology. Paper presented at the Oxford Ontologies Workshop. Retrieved from http://www.sbs.ox.ac.uk/sites/default/files/Research Areas/Science And Technology/Docs/Lynch.pdf 
Mariott, J., \& Minio-Palluello, M. (2013). Where does this stuff come from? Oil plastic and the distribution of violence. In J. Gabrys, G. Hawkins, \& M. Michael (Eds.), Accumulation. The Material Politics of Plastic (pp. 171-183). London: Routledge.

Meikle, J. L. (1995). American plastic: a cultural history. Rutgers University Press. New Brunswick,NJ: Rutgers University Press.

Miller, D. (1998). Material Cultures. Why Some Things Matter, Chicago, IL: The University of Chicago Press. Nowotny, H. (1994). Time. The Modern and PostModern Experience. Cambridge: Polity Press.

Passet, R. (1992). L'économique et le vivant. Paris: Economica.

Poirot-Delpech, S. (2017). Nuclear waste: An untreatable technoscientific product. In B. Bensaude Vincent, S. Loeve, A. Nordmann, \& A. Schwarz (Eds.), Research Objects in their Technological Setting (pp. 232-244). Abington: Routledge.

Preda, A. (1999). The Turn to Things: Arguments for a Sociological Theory of Things. Sociological Quarterly 40(2), 347-366.

Proctor, N., \& Schiebinger L. Eds. (2008). Agnotology. The Making and Unmaking of Ignorance. Stanford, CA: Stanford University Press.

Raineau, L. (2012). Regard socio-anthropologique sur les choix énergétiques d'aujourd'hui: la question du nucléaire civil. In M.-H. Parizeau \& J.-P. Pierron (Eds). Repenser la nature. Dialogue philosophique, Europe, Asie, Amériques (pp. 431-449). Laval: Presses de 1'Université de Laval.

Rosa, H. (2013). Social acceleration: A new theory of modernity. New York: Columbia University Press. Serres, M. (1977). La distribution. Hermes IV. Paris: Editions de minuit.

Serres, M. (1992). Eclaircissements, Entretiens avec Bruno Latour. Paris: Editions François Bourin. English edition: Serres, M., \& Latour, B. (1995). Conversations on Science, Culture and Time (trans: Lapidus, R.). Ann Arbor, MI: University of Michigan Press.

Serres, M. (1977). La naissance de la physique dans le texte de Lucrèce. Fleuves et turbulences. Paris: Editions de minuit. English edition: Serres, M. (2000). The Birth of Physics (trans: Hawkes, J.). New York: Clinamen Press.

Serres, M. (1982). Genèse. Paris: Grasset. English edition: Serres, M. (1995). Genesis (trans: James, G. \& Nielson, J.). Ann Arbor, MI: The University of Michigan Press.

Serres, M. (1990). Le contrat naturel. Paris: Editions François Bourin. English edition: Serres, M. (2012). The Natural Contract (trans: MacArthur, E., \& Paulson, W.). Ann Arbor, MI: The University of Michigan Press. Serres, M. (2001). Hominescence. Paris: Le Pommier.

Serres, M. (2010). Biogée. Paris: Le Pommier.

Simondon, G. (1958). Du Mode d'existence des objets techniques. Paris: Aubier (2013 edition). English edition: Simondon, G. (2016). On the Mode of Existence of Technical Objects (trans: Malaspina, C.). Minneapolis, MN: Univocal Publishing.

Sklar, R. (1970). The Plastic Age (1917-1930). New York: George Braziller.

Souriau, E. (1939). L'instauration philosophique. Paris: Félix Alcan.

Souriau, E. (1943/2009). Les différents modes d'existence. Paris: Presses universitaires de France.

Verbeek, P.-P. (2005). What Things Do. Philadelphia, PA: The Pennsylvania State University Press.

Verbeek, P.-P. (2006). Materializing morality: design ethics and technological mediation. Science, Technology, and Human Values, 31(3), 361-380.

Verbeek, P.-P. (2008). Design ethics and the morality of technological artifacts. In P. E. Vermaas, P. Kroes, A. Light, \& S. A. Moore (Eds), Philosophy and Design. From Engineering to Architecture (pp. 91-100). Dordrecht: Springer.

Wajcmann, J. (2014). Pressed for Time: The Acceleration of Life in Digital Capitalism. Chicago, IL: University of Chicago Press.

West-Pavlov, R. (2013). Temporalities. London: Routledge.

Winner, L. (1986). Do artifacts have politics? In L. Winner, The Whale and the Reactor. Chicago, IL: The Chicago University Press. http://faculty.georgetown.edu/irvinem/theory/Winner-Artifacts-Politics.pdf. Accessed 31 July 2016.

Woolgar, Steve and Cooper, Geoff (1999). Do artefacts have ambivalence? Moses' bridges, Winner's bridges and other urban legends in S\&TS. Social Studies of Science 29: 433-449.

Zalasiewicz J., Waters C., Ivar do Sul J, et al. (2016) The geologic cycle of plastics and their use as a stratigraphic indicator of the Anthropocene, Anthropocene Review, March 2016, pp. 4-17. 